\title{
"Pas de Marine": F. D. Monk and Henri Bourassa's Nationaliste Crusade against Canada's Naval Policies 1909 to 1913
}

\section{Peter K. H. Mispelkamp}

Henri Bourassa et ses admirateurs nationalistes critiquaient ouvertement l'appui que l'armée canadienne offrait automatiquement à l'Empire britannique, à moins que le Canada ne soit directement menacé. Avant 1914, lorsque l'hégémonie navale de l'Empire britannique était contestée, ils étaient fermement convaincus que la politique navale du Canada de 1909 à 1913 allait entraîner le pays dans tous les conflits de l'Empire. Cet article examine l'évolution de l'opposition nationaliste à la politique navale du Canada au cours de cette période dans l'optique des relations entre Bourassa le "libéral » et son allié anti-naval «conservateur » Frederick Debartzch Monk, dont les affinités nationalistes avaient tendance à éclipser leurs idéologies politiques divergentes.

\section{Introduction}

As one of Britain's largest colonies, Canada faced many challenges in the period 1896 to $1914 .{ }^{1}$ The most severe of these centered on the unwillingness of

\footnotetext{
1 I need to thank Dr. Cameron Nish (History Department of Concordia University) for first suggesting this topic to me and to Dr. Olaf Janzen (History Department, Memorial University) for agreeing to review a preliminary draft of this updated manuscript. I would like to express my gratitude to my bilingual proof readers, Lise Dupont, Mathieu Lamontagne, Jean-Jacques Picard, Ronald Pétion, Guylaine St-Louis and Julien Wholhuter who took the time to review this manuscript. Estelle Santerre managed to obtain a much-needed book for me. Their contributions, suggestions and corrections have enhanced this text considerably. However, I alone am responsible for any errors that may have slipped though.
}

The Northern Mariner / Le marin du nord, XXIX, No. 2 (Summer 2019), 109-34 


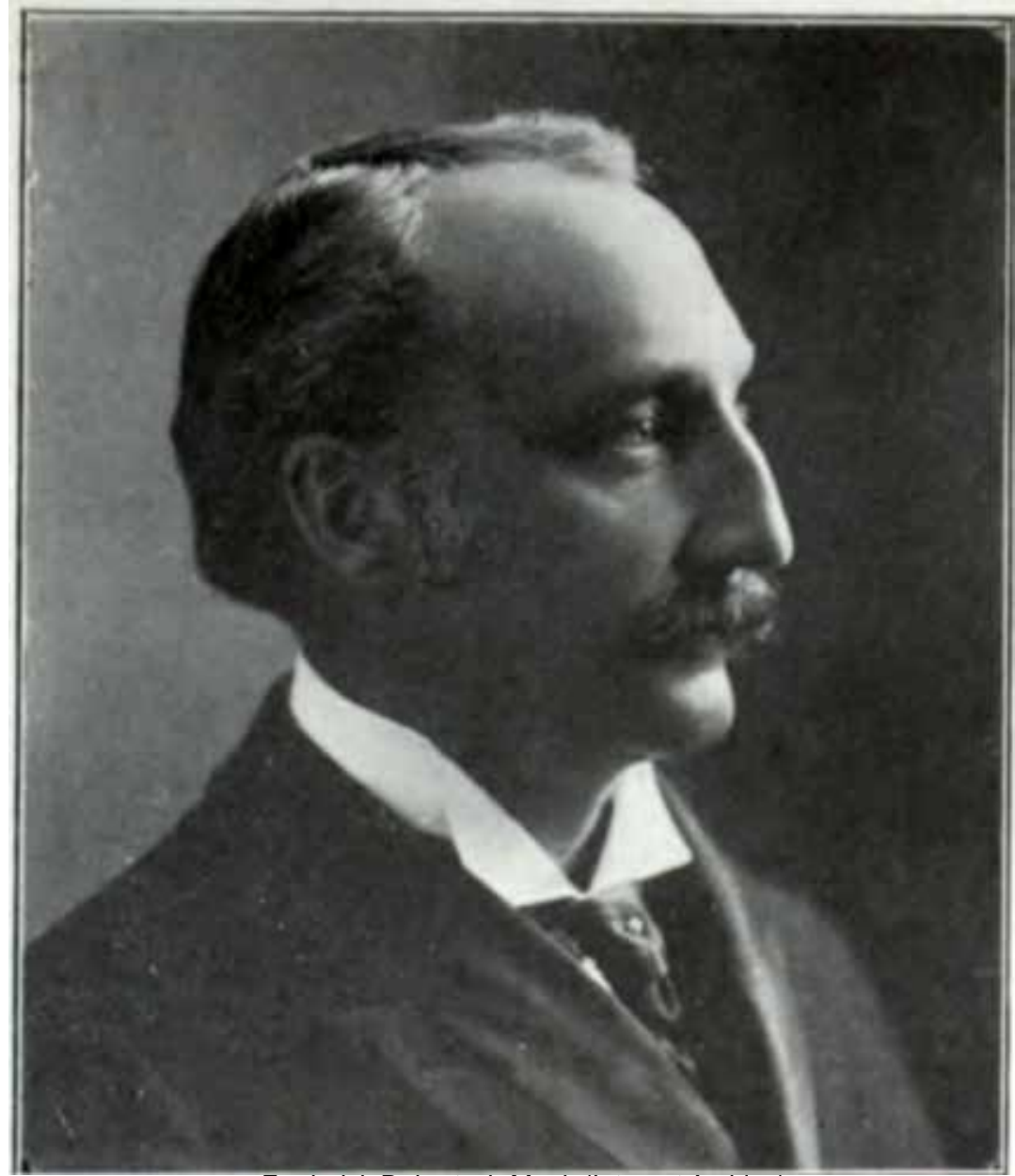

Frederick Debartzch Monk (Internet Archive)

its French co-founders to defend the empire. This reluctance eventually fostered the emergence of French-Canadian nationalism under the loose influence of Henri Bourassa. He was a disenchanted Liberal MP who left federal politics in 1907, then served as a member of the Quebec legislature until 1912 as a nationaliste representative and founded Montreal's Le Devoir in $1910 .^{2}$ Bourassa and his followers, known as the nationalistes, were open critics of any blind military support for the British Empire throughout the globe such as the Boer War. Not surprisingly, when the Britain was faced with a serious threat to its control of the seas, the position of Bourassa and his nationaliste admirers stimulated another political crisis. The evolution of their opposition to Canada's naval policies in the period 1909-1913, as revealed by the relationship between Bourassa and his main

2 Susan Mann Trofiminkoff, The Dream of Nation: A Social and Intellectual History of Quebec (Toronto: Gage Publishing Ltd, paperback ed., 1983), 169-171, 174-175. 


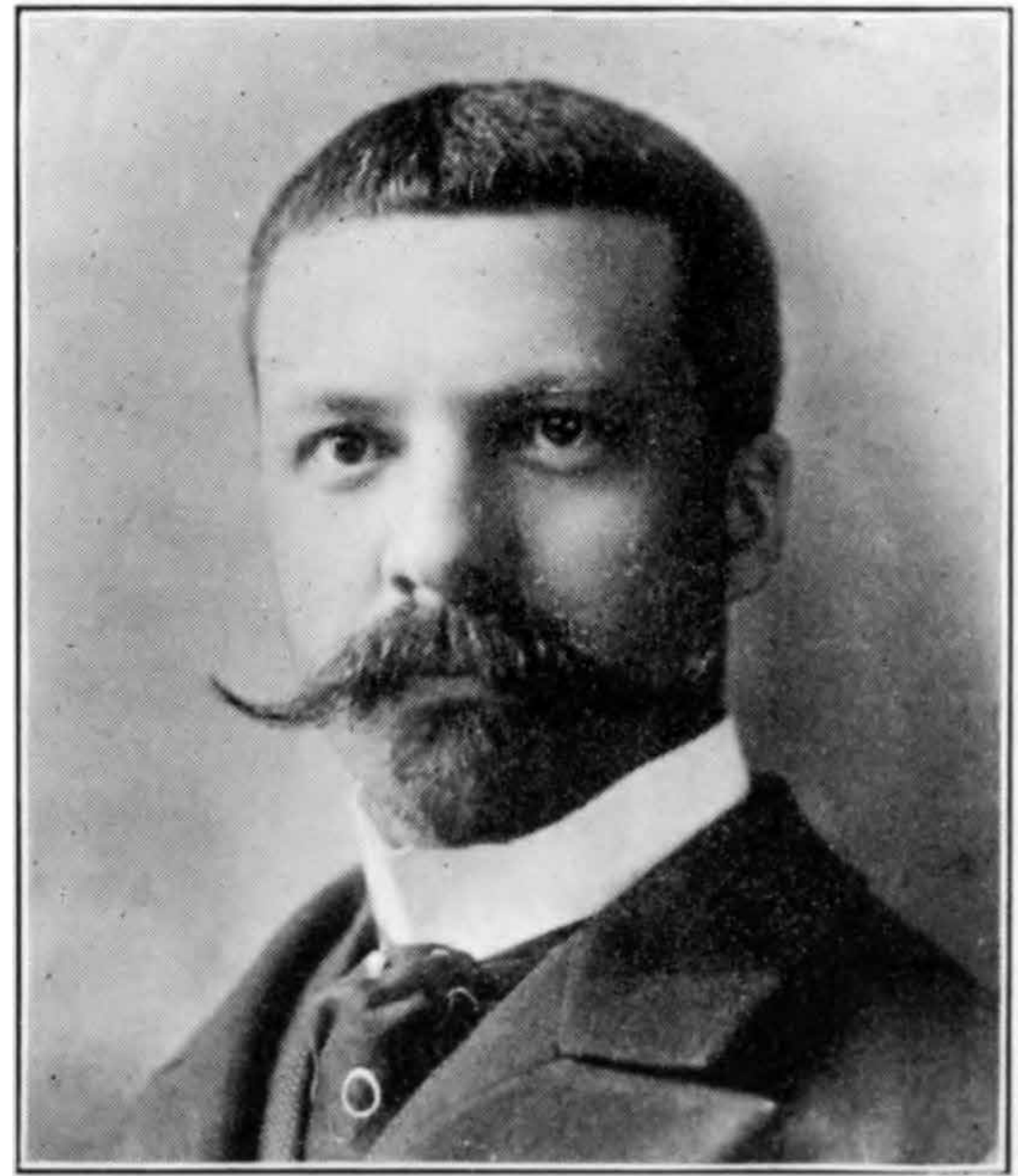

Henri Bourassa (Internet Archive)

anti-naval ally, Frederick Debartzch Monk is examined here. Monk was the son of an Acadian Loyalist family and a French Canadian Conservative MP who served in the House of Commons from 1896 to $1914 .^{3}$

\section{The Evolution of a Political Crisis}

At the turn of the twentieth century, the Royal Navy was the largest naval power in the world but imperial Germany was a serious rival. Britain's lead in warships was insurmountable until 1906 when the introduction of HMS Dreadnought, an all-biggun battleship started a new naval construction race. In 1909 a naval panic took

3 John English, "The 'French-Lieutenant' in Ottawa" in R. Kenneth Carty and W. Peter Ward, eds., National Politics and Community in Canada (Vancouver: University of British Columbia Press,1986), 191. 
hold of the popular press and imagination within England and its empire. While Australia and New Zealand immediately offered aid to the mother country, Canada seemed to dither. All of this changed in March when George Foster, a Conservative MP, challenged the government to assume responsibility for protecting its coasts and harbours declaring that "Canada should no longer delay in assuming her proper share of responsibility and financial burden incident to the suitable protection of her exposed coastline and great seaports." 4

Although Foster's motion was first proposed on 21 January it was only formally presented on 29 March. Foster knew that opposition to any major naval initiative existed within his party, especially from its French Canadian lieutenant, F. D. Monk. In fact, one Conservative MP is reported to have remarked, "The party owes no thanks to this gentleman whose sole aim is to put us in the hole and keep us there." After intense political negotiations with the leader of the Conservative party, Robert Laird Borden, Laurier introduced a modified version of Foster's resolution which declared that "The House will cordially approve of any expenditure designed to promote the speedy organization of a Canadian Naval Service." ${ }^{\prime 6}$ In effect, Laurier had transformed the original motion drastically. Foster's carefully drafted motion was intended to focus on coastal defence, but Laurier's motion allowed for the creation of a full-fledged Canadian navy. After years of avoiding a naval policy, Laurier now seemed to have a nation wide consensus to implement one. However, within the span of a few months, this rare show of unanimity had melted away and his naval policy triggered one of the most divisive debates in Canadian history.

When opposition to Laurier's naval policy materialized, Bourassa was not the first one to sound the nationaliste alarm bells about its perceived dangers because he was heavily distracted on two fronts. ${ }^{7}$ Consequently, that honour fell to F. D. Monk, who first publically expressed his opposition in a speech at Lachine on 9 November 1909. ${ }^{8}$ Like Bourassa, Monk had a rather stormy relationship with Borden, who once characterized him as being "extremely difficult to work with." During the period 1901-1904, Monk was Borden's Quebec lieutenant, and even in this period he had cautiously refrained from supporting any naval initiatives. ${ }^{10}$

4 House of Commons Debates 1909 Vol. II, (Ottawa: Government of Canada, n. d.) col. 3484. Hereafter cited as Debates.

5 Robert Craig Brown, Robert Laird Borden: A Biography (Toronto: Macmillan Canada, 1975), $1: 153$.

${ }^{6}$ Debates, col. 3563. Significantly, Laurier managed to get Borden's reluctant agreement to abandon his recommendation of an emergency financial contribution to the Royal Navy.

7 These were his provincial election campaign Quebec, Trofimenkoff, 175, and his newspaper project, Réal Bélanger, Henri Bourassa. Le fascinant destin d'un homme libre (1868-1914) (Laval, Quebec: Les Presses de l'Université Laval, paperback ed., 2013), 298.

8 “The Naval Policy - Mr. F. D. Monk M.P. Gives his Reasons for Being Opposed to It." The Montreal Gazette, 9 November 1909, 6-7, hereafter cited as Monk's Speech.

9 Henry Borden, ed., Robert Laird Borden: His Memoirs, 1854-1915 (Toronto: Macmillan Canada, 1938), 1: 334 .

10 William Johnston, William G. P. Rawling, Richard H Gimblett, and John MacFarlane. The 
In 1904 Monk resigned, complaining bitterly to a Quebec nationaliste paper about his stormy relationship with his party's membership which contained: "des élements qui, clairement, ne [lui] sont pas sympathiques, qui [lui] sont même hostiles." ${ }^{11}$ Nonetheless, Monk was so highly regarded by the Quebec wing of the Conservative party that even in the period 1904-1909 the majority of them saw him as being their unofficial spokesman. Borden finally reappointed Monk in early 1909 and he retained this role for most of his remaining parliamentary career. Monk's main condition for reinstatement was that he would have full responsibility for determining the party's position and platform in Quebec.. ${ }^{12}$

During the debate on Laurier's subsequent naval legislation, Monk was challenged on his position and vote on Foster's resolution. In response, Monk claimed that: "The moment I saw that motion on the orders of the day, I freely said to those who sit on this side of the House, and too many of my friends on the other side, that I could not approve that motion." 13 At another time, he denied having openly opposed it, maintaining that "I had stated the other day that I had thought it was inopportune." ${ }^{14}$ Much later, Monk stated that "I voted on that occasion, Sir, for that resolution [Foster's], and I have never regretted it, and I would do the same under similar circumstances." 15 If this was true, then something must have happened to change his position between the passing of the resolution and later events. At Lachine in November 1909, Monk stressed that the purpose of Foster's motion was to promote the creation of a force to protect Canada's coasts, not to support the Royal Navy in all of its overseas entanglements. ${ }^{16}$ An even more definite statement of Monk's position on Laurier's naval scheme came later during the naval debate. In a letter to Bourassa, dated 6 February 1910, Monk argued that "Les vaisseaux que le gouvernement veut construire, les croiseurs, constituent une preuve évidente que la défense de nos côtes n'est pas l'objet en vue, mais bien de satisfaire au désir de 1'amirauté d'avoir des vaisseaux rapides et auxiliaires de la flotte; on ne protège pas un pays avec des croiseurs jaugeant 4000 tonnes." ${ }^{17}$

Seabound Coast: The Official History of the Royal Canadian Navy, 1867-1939 (Toronto: Dundurn Press, 2010), 64.

${ }^{11}$ Cited in Réal Bélanger, L'Impossible Défi: Albert Sévigny et les Conservateurs Fédéraux (19021918). (Laval: Les Press de l'Université Laval, 1983), 24. Square brackets are his.

${ }^{12}$ Ibid., 56-57; François Béland, "F. D. Monk, le Parti Conservateur Fédérale et l'idée d'un Canada pour les Canadiens (1896-1914)" ( MA thesis, Laval University, 1986), 73.

${ }^{13}$ Debates 1909-1910, Vol. I, col. 1770.

${ }^{14}$ Debates 1909-1910 Vol. II, col. 2955-6.

15 Debates 1911-1912, Vol. I, col. 234. In his Lachine speech, Monk actually said that: "Under the circumstances, no one would have dreamed of entering a dissent." Monk, Speech, 9 Nov. 1909. Bélanger maintains that Monk was absent for the final vote on the Naval Resolution on 29 March 1909 but this claim is undocumented, (Henri Bourassa, 300 n. 68). On 29 November 1910 Laurier was also confused regarding Monk's presence - but he couldn't resist pointing out that Monk did not dissent. See Debates 11th parliament, 3rd session (17 November 1910 - 18 January 1911 online ed.). Ottawa, 1911, 443.

${ }^{16}$ Monk's Speech 9 Nov. 1909, 6.

${ }^{17}$ Monk to Bourassa, Ottawa, 6 February 1910. In 1988 Mlle Anne Bourassa, daughter of Henri 
On 19 May 1909 Monk had expressed his continuing anxiety over Laurier's naval policy by questioning the mandate of Canada's two representatives to the Imperial Conference of July, 1909. "Will the two ministers who will represent Canada at this conference have the power to make any binding agreement or just to discuss proposals which will only become effective after having been laid before Parliament and discussed?"18 Even before his Lachine speech, Monk had been identified as being either a valuable potential ally for Laurier's naval policy or as a potential leader of French Canadian opposition to it. ${ }^{19}$ This certainly explains the five-page letter which the governor general, Lord Grey, wrote to Monk on 20 May 1909. In tone it sounded a very pessimistic note regarding the probable outcome of the naval race.

The enclosed figures will show you that if Germany is earnest in her endeavour to wrest the trident from our grasp, it will be difficult for England to prevent her. A tug of war between 40 odd million and 60 odd million men, who are superior to ourselves, can only have one result eventually, however hard we may struggle. There is no part of the British Empire which stands to lose more than the Province of Quebec, from any naval disaster that may befall the British Crown. ${ }^{20}$

Grey amplified the latter comment with the observation that "One German cruiser in the mouth of the St. Lawrence would put every Quebec farmer out of business."21 He argued that Laurier's naval project would benefit Quebec and Canada. He also stressed that while he did not question the loyalty of French Canadians to the empire, he was deeply concerned by the lack of accurate information on the naval crisis available to them. To this end, he suggested that an effort be made to establish a pro-navy lobby group in Quebec. In fact, he actually suggested that Monk should form this group!

The predominant issue of the Imperial Conference of 1909 was the naval question. Although the Admiralty would have preferred a balanced fleet unit including a battlecruiser and smaller vessels, it was still pleased with the change in Canada's naval policy. In the end, Canada decided to obtain three cruisers of the improved Bristol class, and four destroyers from the River class. Additionally,

Bourassa and custodian of many of his papers, gave me a collection of photocopies which remain in my possession. They are cited here as Bourassa Papers. In 1959 Dr Cameron Nish had catalogued many of them, and those are the numbers used here. As the letters seldom had page numbers, second and subsequent pages are indicated by the letters $\mathrm{A}$ and so forth. The originals have since been deposited at the Library and Archives Canada, Ottawa. The LAC finding aid incorporates the Nish numbering system. 268C-D/Monk 4,C-D.

18 Debates, 1909, Vol. IV, col. 7084

19 Richard H Gimblett. "Reassessing the Dreadnought Crisis of 1909 and the Origins of the Royal Canadian Navy," The Northern Mariner/Le Marin du Nord 4:1 (January 1994), 40.

${ }^{20}$ Lord Grey to Monk, Ottawa, 20 May 20, 1909, Library and Archives of Canada, Ottawa, Frederick Debartzch Monk papers, MG 27 II D 10 A (hereafter Monk papers) 1: 94.

21 Ibid., 97. 
the Admiralty also undertook to sell Canada two aging cruisers for training purposes. ${ }^{22}$ Critics from Toronto Conservative papers were quick to point out that the younger of the two ships had already been destined to be scrapped long before her sale to Canada. ${ }^{23}$ In an attempt to avoid grist to Bourassa's mill, the Canadian representatives tacitly agreed to allow the Royal Navy to stipulate that the "working language" of the Royal Canadian Navy would be English. ${ }^{24}$ With these issues decided, the Canadian government began to draft its Naval Service Act which was introduced on 12 January 1910.

While the Laurier government was busy drafting its naval legislation, Borden was attempting to keep his party united. In this vein, he asked Monk and another French Canadian Tory MP to avoid being "carried away by the excitement of the moment." 25 Before delivering his speech of 9 November 1909 Monk took the precaution of informing his party leader that "I will try to avoid expressing views which might clash with those of our friends." ${ }^{26}$ Nonetheless, at Lachine, Monk soundly denounced the direction of Laurier's naval policy. He argued that the introduction of any naval-related measure "without submitting it to the judgement of the electorate" violated Canada's right to self-rule. ${ }^{27} \mathrm{He}$ also maintained that Canada did not have the financial resources to build a navy - an argument that Laurier himself had used earlier. ${ }^{28} \mathrm{He}$ reminded his audience that Canada had no need for a fleet because only the United States posed a direct military threat to her survival. He also predicted that by the time a Canadian fleet would be operational, the anticipated European war would probably have ended. He declared that he was not opposed to the proposition that Canada should be prepared to defend itself, but felt that: “Ce pays n'a donc aucune obligation envers l'Angleterre et l'Empire, et il n'en aura que s'il participe un jour à ses décisions." 29

Monk knew that his public stand on this issue would expose the gulf that existed between him and Borden. Consequently, he was quick to inform newspapers that "Je le [Borden] regarde comme le chef des conservateurs et je serais peiné que quelqu'un peut croire autrement." 30 In an interview with a Toronto newspaper, Monk remarked that his "own interests would be best served by adopting a "nationalist attitude" which he hoped would unite Quebec behind him and allow

${ }^{22}$ Maurice Olivar, ed., The Colonial and Imperial Conferences from 1884 to 1937 Vol. II, Part 1,

${ }^{23}$ Marc Milner, Canada's Navy: The First Century (Toronto: University of Toronto Press, 1990) 19.

24 Johnston, 160-161.

25 Cited in Brown, 153.

${ }^{26}$ Béland, 80-1. See also Monk's Speech 9 Nov. 1909, 6-7. Béland's summary appears to be very accurate.

${ }^{27}$ Cited in Brown, 158. Béland maintained that Monk was actually challenging Laurier to fight an

${ }^{28}$ Imperial Conferences, Vol. I, 1887-1907, 161.

${ }^{29}$ Cited in Béland, 82.

${ }^{30}$ Ibid., 82-3. 
him to remain a loyal member of the Conservative party." ${ }^{31}$ Reaction to his speech was not long in coming. On 15 November Laurier assailed Monk's speech in the House of Commons. "Need I say to my honourable friend that whether we have such a navy or not, we do not lose our right to self-government; that if we do have a navy, that navy will go to no war unless the Parliament of Canada, including that honourable gentleman, will choose to send it." 32 However, Laurier's position was technically incorrect. As a part of the British Empire, Canada was automatically considered to be at war when England was. Monk and other prominent nationalistes feared that the mere possession of an ocean-going fleet would result in automatic Canadian participation in all of England's future conflicts overseas. For them this was unacceptable since Canada did not have any voice in determining England's foreign policy.

Not surprisingly, the most positive reactions to Monk's speech came from the nationalistes. On 16 November Armand Lavergne, one of Bourassa's key admirers and supporters, wrote Monk.

Il y a longtemps que je désire vous écrire au sujet de votre beau discours du 8 novembre, mais les élections partielles ont pris tout mon temps. Je n'ai pas besoin de vous dire comme je suis de cœur et d'esprit avec vous, c'est ça, la raison même, le simple bon sens que vous avez exprimés si éloquemment, et l'opinion saine a en vous un porte-parole. Il est amusant de voir Laurier poser au loyaliste et rougir de vos paroles....Quel cynisme. Le vieux parti conservateur français a enfin, par vous, retrouvé sa voie. ${ }^{33}$

Henri Bourassa's public reaction was delayed until 10 January 1910. In his newspaper article of that date, the first edition of Le Devoir, he commented: "Le discours retentissant de M. Monk à Lachine nous donne l'espoir que la situation dangereuse et abrutissante où nous étions ne durera pas. Le député de Saint-Jacques peut-être assuré de notre appui s'il maintient son attitude avec fermeté, logique et persevérance." 34

\section{The Crusade Begins}

Once the Naval Service Act was introduced in the House, Monk made certain that everyone was well informed regarding his position. "I have the misfortune to differ from many on this side of the House - and apparently from all on the other side - on this question." ${ }^{35}$ After this admission, he reiterated the reasons for his opposition

\footnotetext{
31 Cited in Ronald Michael Allen, "Borden, Britain and the Navy 1909-1914" (unpublished MA thesis, University of Calgary, 1972), 47.

32 Debates 1909-1910, Vol. I, col. 49

33 Monk Papers, Vol. 1, “Armand Lavergne to Monk, Quebec City, November 16, 1909”, Vol. 1, 99.

34 Cited in Béland, 86.

35 Debates 1909-1910, Vol. 1, col. 1769. Unless indicated otherwise all the information presented on this speech comes from this source, cols. 1769-1775.
} 
to this measure. Essentially, he repeated the same arguments that he had made in Lachine the previous November. He then voiced his over-riding concern on the potential consequences of this legislation,

"...that if we are to carry out this policy we shall find ourselves in the position that we become responsible jointly and severally with the people of the British Isles for the foreign policy of the empire, and mind you without having had a single voice in the formation of that policy." ${ }^{36} \mathrm{He}$ also declared that: "I do not speak [only] for the province of Quebec; I say that you will never find AngloSaxons who will willingly bend their heads to what I consider to be an infraction of the ancient rights of British subjects established centuries ago in England." ${ }^{37}$ When he made this speech, Monk was most likely already starting to suffer from his yet to be diagnosed arteriosclerosis and this illness would limit his effectiveness throughout the naval debate..$^{38}$ At that time, he was also essentially a lone voice in the wilderness. However, that situation was about to undergo a drastic change.

Until 17 January 1910 Monk and Bourassa do not appear to have been in direct contact with each other in regards to the naval issue nor indeed on any other. ${ }^{39}$ Unfortunately, we do not know exactly when Monk and the nationalistes first came together. At least one source maintains that serious contact between them occurred earlier, pointing out the ideological affinity they had on all the divisive French-English issues in the period from 1896 to 1909 and claiming that early on "Bourassa was soon joined by F. D. Monk." 40 However, as late as January 1909, Monk rebuffed an overture from Bourassa to enter into a formal alliance, because he felt that they were politically far apart. ${ }^{41}$ This situation changed later that year, as evidenced by a letter from Lavergne dated 16 November 1909. Indeed, this is the first document that conclusively indicates that Monk's political opposition to Laurier's naval policy had found support within nationaliste circles. It also predates the first written communication found between Monk and Bourassa in their private papers and archives which is dated 18 January $1910 .^{42}$ Nonetheless, given their family ties, shared nationaliste sympathies and the fact that they were both sat as MPs in the period 1901 - 1907, they obviously knew each other prior to January $1910 .{ }^{43}$ However, assertions of any direct and meaningful contact between them that predate the naval issue are not borne out by archival evidence. In any

${ }^{36}$ Ibid., col. 1774. These included the fact that the resolution of 1909 had been passed in the midst of a war scare and Canada's inability to afford a combat fleet.

${ }^{37}$ Ibid., co1. 1775.

${ }^{38}$ Béland, 3.

39 Monk to Bourassa, Ottawa, 17 January 1910, Bourassa Papers, 262/Monk 1, Unless otherwise indicated all the information presented on this letter stems from this source.

40 Johnston, 63.

${ }^{41}$ Bélanger, Henri Bourassa, 252.

${ }^{42}$ Bourassa to Monk, [Montreal?] 18 January 1910, Bourassa Papers, 262/Monk 1.

${ }^{43}$ In 1905 Bourassa praised Monk's initiatives in support of French education in western Canada and apparently some form of political collaboration between Monk and the nationalistes was explored in 1907. See Bélanger, Henri Bourassa, 206 \& 252. 
case, the eventual political alliance between "the unpredictable Conservative, F. D. Monk, and the predictable nationalist, Henri Bourassa" 44 was to cause both Borden and Laurier much grief.

According to Monk, the first impetus for direct contact between them occurred through someone only identified as Léonard in Monk's first letter to Bourassa regarding Laurier's naval policy. Léonard had apparently tried to interest Monk in joining the huge anti-naval act rally which Bourassa was planning. In this very significant letter, Monk expressed his approval of Bourassa's plan to give a public speech against the naval act on 20 January, at Montreal's Monument National. Despite his affinity with Bourassa on this issue, Monk informed the Le Devoir's editor that he would not be able to participate in the planned rally. He listed several reasons, including other pressing concerns in Ottawa, and the fact that he was feeling the ill-effects of his still undiagnosed illness. He also informed Bourassa that he might not be able to play a major role during the second reading of the bill for the same reasons. Nonetheless, he assured Bourassa that their views were similar on this issue. He also outlined his preferred strategy for dealing with this legislation.

Dans ces circonstances, je préfèrerais commencer ce travail si essentiel de l'éducation de l'électorat quand celui de la discussion ici sera terminé. Mais comme je le disais à Léonard, si vous voulez commencer ce travail par une grande assemblée au Monument, ne vous gênez pas pour le faire malgré mon absence. Les assemblées de ce genre ne peuvent pas être trop nombreuses. J'ai subi bien des déboires ici comme résultat de l'attitude que j'ai prise. ${ }^{45}$

He then made an important observation, and offered an even more valuable suggestion.

Enfin, bien que le peuple soit, sans doute d'instinct, opposé à cette politique fausse et dangereuse, ceux qui parlent par lui semblent hypnotisés. Pour faire face à tant d'éléments adverses, il faut, dans la discussion en Chambre, être armé le pied en cap et cela demande des recherches et des études préparatoires. Si je puis être préparé, je mettrai au Hansard le résultat de cette préparation et j'ose croire qu'il sera utile à nos amis qui voudront, en dehors du Parlement, discuter cette question. ${ }^{46}$

This suggestion hints at their ultimate demand for a plebiscite on Laurier's naval policy.

\footnotetext{
${ }^{44}$ Ramsay Cook, "Craig Brown's Logical Reason” in David Mackenzie, ed., Canada and the First World War: Essays in Honour of Robert Craig Brown. (Toronto: University of Toronto Press, 2005), 25.

${ }^{45}$ Fd monk - b 17 jan 10 Bourassa Papers, 262/Monk 1.

${ }^{46}$ Ibid., 262A/Monk 1A.
} 
One must wonder if Monk's decision not to participate in Bourassa's first public foray into the naval question could also be explained by factors other than those given in this letter. After all, they were just taking their first few tentative steps towards an eventual collaboration. More than likely, Monk was not ready to burn his bridges by making a far too hasty move towards Bourassa and avoid a premature break with Borden on the naval question. ${ }^{47}$ Seen in this light, Bourassa's response of 18 January was obviously meant to reassure Monk that while they did agree in general, they could still disagree on tactics and specifics. Nonetheless, Bourassa noted his disappointment regarding Monk's decision not to participate in the rally. The editor of Le Devoir then went on to say that:

Je reconnais qu'il y a deux manières d'envisager la situation et qu'il est peut-être préférable que vous fassiez votre premier et votre principal discours à la Chambre des Communes. Nous allons préparer le terrain ici et vous donner un bon coup d'épaule. Je crois que l'assemblée de jeudi aura un grand retentissement. Je me propose d'assister au débat sur la deuxième lecture. Ne vous découragez pas en face de toutes les petitesses que vous allez rencontrer sur votre route..$^{48}$

Bourassa gave his first major public speech against the Naval Service Act in Montreal on 20 January 1910. He mentioned Monk approvingly on several occasions in it. Monk's Lachine speech was noted, as well as his continued opposition to Laurier's naval policy. He further credited Monk as being the first politician to realize that this policy had an inherent escalator clause. This was because replacement vessels would invariably cost more to build than their predecessors. Bourassa agreed with Monk that the construction of Laurier's proposed fleet would result in Canadian participation in all of England's armed conflicts. He also supported Monk's cogent argument that building a fleet would divert federal funding from Canada's more urgent needs. ${ }^{49}$

Bourassa's speech certainly made an impression upon Monk, as is indicated by his letter to Bourassa the day after this speech. In it he stated that he had been very anxious to study the accounts in several newspapers. He gave a quick summary of those papers that he had examined. 'Le Canada m'est arrivé d'abord avec un compte rendu mal fait, puis la Montreal Gazette avec un rapport juste qu'il permet de bien apprécier votre conférence et ce qu'il s'y est passé. Je vous en félicite sincèrement et je suis certain que votre discours et cette assemblée aideront puissamment à répandre des idées saines sur la politique néfaste où l'on veut engager notre jeune pays." 50

\footnotetext{
47 Béland, 89.

48 Bourassa to Monk, [Montreal?], 18 January 1910, Bourassa Papers, 264/Monk 2.

49 Henri Bourassa, La Projet de la Loi Navale: Sa Nature, Ses Conséquences: Discours prononcé au Monument National le20 janvier 1910 (Montreal: Le Devoir, 1910) , 4, 7, 13, and 27.

50 Monk to Bourassa, Ottawa, 21 January 1910, Bourassa Papers, 265A/Monk 3A.
} 
This was Monk's first private endorsement of Bourassa's position and clearly indicates that the Conservative MP's doubts about collaboration were disappearing. Monk's main gain from an alliance with Bourassa was that the latter's vast contacts throughout Quebec and the nationalistes were now at his disposal. This would allow him to spread his anti-naval and pro-Conservative message throughout the entire province. As for his newfound ally, as at least one historian noted, "In Parliament, Bourassa once again had a voice." ${ }^{51}$ Together, they now braced themselves for the next step in the bill's passage.

As things developed, Monk was able to participate in the bill's second reading. ${ }^{52}$ On 3 February he presented his main argument against the bill which focussed on this key clause. "In case of emergency the Governor in Council may place at the disposal of His Majesty, general service in the Royal Navy, the Naval Service or any part thereof, any ships or vessels of the Naval Service, and the officers and seamen serving in such ships or vessels, or any officers or seamen belonging to the Naval Service." ${ }^{53} \mathrm{He}$ maintained that this clause boded ill for Canada. "Therefore, I say this Section 18 enunciates a new principle; when it says that the Governor in Council may if it chooses, place the navy at the disposal of the British Government." ${ }^{54}$ For him, this was just another example of Laurier's perfidy, because it clearly allowed the fleet to be committed to action without the prior approval of Parliament. He went on to argue that Canada would become directly entangled in England's conflicts. He argued that this would happen despite the fact that: "We receive no guarantee as to the maintenance of the integrity of our own Dominion. Most important of all, we have no voice of any kind in the conduct of imperial affairs, while being bound by imperial obligations towards foreign countries. We become liable to the political and financial results of those obligations, without any representation, or administrative responsibility." ${ }^{55} \mathrm{He}$ expanded on this point in a letter to Bourassa dated 6 February. "Tout ce projet veut dire pour nous la taxe directe à brève échéance; i1suffit de jeter les yeux sur nos comptes publics, pour s'en convaincre. ${ }^{56}$

In his speech on the second reading of the bill, Monk stressed that he was not opposed to Canada assuming a greater degree of responsibility for the protection of her territorial waters. However, in his view, the proposed naval act went far

\footnotetext{
51 Casey Murrow, Henri Bourassa and French Canadian Nationalism: Opposition to Empire (Montreal: Harvest House, 1968), 65.

52 Debates 1909-1910, Vol. II, cols. 2991-3022.

${ }^{53}$ Ibid. Text of the Naval Service Act is at Gilbert Norman Tucker, The Naval Service of Canada: Its Official History (Ottawa: King's Printer, 1952) 1: 377-385. The section that Monk was referring to is to be found on 380. For some reason, this section was referred to as Section 18 during this exchange, but in this source it is Section 23. Most likely, this discrepancy can be explained by subsequent redrafting.

${ }^{54}$ Debates 1909-1910 Vol.II, col. 3004.

${ }^{55}$ Ibid., col. 3007.

${ }^{56}$ Henri Bourassa to F. D. Monk, 18 January 1910, emphasis in the original, Bourassa Papers, 268D/ Monk 4D.
} 
beyond that limited aim. Therefore, he demanded that the government present its policy to the electorate for their approval. For this reason, he decided to move a sub-amendment to the amendment previously offered by Borden: "This House, while declaring its unalterable devotion to the British Crown, is of the opinion that the Bill now submitted for its consideration changes the relations of Canada with the empire and ought in consequence to be submitted to the Canadian people in order to obtain at once the nation's opinion by means of a plebiscite." ${ }^{57}$ During this debate, several Liberal attempts were made to drive a wedge between Monk and Bourassa. One example is to be found in the comments of a government member, Post-Master General Rodolphe Lemieux. He criticized the position of the naval bill's nationaliste opponents. In particular, he declared that they were arguing that Canada would be defended by the Americans should she ever be invaded. Monk immediately interrupted Lemieux and asked him to identify the spokesman of this group. Lemieux did so gladly: "I read it in the first place in the Blue press of the province of Quebec; in the next place, it was expounded the other evening, during a three hours' speech, by the ally of my hon. friend [Monk], the ex-member for Labelle, Mr. Bourassa." ${ }^{58}$ At this point, Monk decided not to press the matter.

Bourassa chose to overlook Monk's failure to counter this assertion and his newspaper praised Monk's overall performance during this stage of the debate. Monk, however, did not feel worthy of Bourassa's praise at this juncture of the debate, and he stated this clearly in a letter dated 6 February : "J'ai lu votre article dans Le Devoir d'hier; il est trop élogieux pour moi. Le fait est que je suis malade, depuis quelque temps, d'un affaiblissement nerveux qui m'ennuie beaucoup bien que mon médecin n'y attache pas d'importance; c'est avec difficulté que j'ai pu faire ce long discours et j'ai dû beaucoup éliminer de la matériel que j'avais préparé." 59 In particular, he felt that he should have responded to the Liberal MP's attack on Bourassa. He explained that Lemieux had caught him off-guard with his reference to Bourassa's speech of 20 January. He had refrained from pursuing the matter because he was unable to recall Bourassa's exact comments on this topic. He then remarked that he had subsequently reread it and felt that Lemieux had indeed distorted Bourassa's position and voiced his full agreement with Bourassa's position.

In this letter, Monk promised to send Bourassa more information on groups which supported their demand for a plebiscite. In this regard, he stressed that "Il faut signaler que la population agricole de l'ouest depuis la vallée de l'Ottawa jusqu'aux Rocheuses réclame ce référendum; il n'y a pas d'isolement de Québec.

Les classes ouvrières du Dominion demandent aussi un plébiscite. C'est une absurdité de dire que Québec est seule à réclamer." ${ }^{60} \mathrm{He}$ also mentioned that there were other aspects of this proposed legislation which would have to be raised

\footnotetext{
57 Debates 1909-1910, Vol.II, col. 3022.

58 Ibid., col. 3031.

59 Bourassa Papers, 268A/Monk 4A.

${ }^{60}$ Ibid., 268B-C/Monk 4B-C.
} 
during the remainder of its passage through the House and Senate. He criticized the editorial statements of the ultra-conservative press which had been attacking the nationalistes naval position for almost a month. He also complained of being a political target in Ottawa. He added that he firmly believed that most people were ignorant of the dangers that Canada would be courting if the bill was passed. He maintained that something had to be done to educate the people to the reality of these potential perils.

The focal point of Monk and Bourassa's anti-naval campaign strategy was their petition demanding that the government should hold a plebiscite on this vexatious issue. Le Devoir played a key role in circulating it, and upon completion it was sent to Monk in Ottawa. ${ }^{61}$ On 15 February Monk formally presented it in the House. ${ }^{62}$ Simultaneously, Monk had to defend his position on the naval bill while professing his loyalty to both Canada and the Crown, challenging a fellow MP to find "in any utterance of mine or of anybody on this side of the House a desire or intent to sever the connection with the British Empire?"63 Later, on 22 February he acknowledged in the House that he fully endorsed the position taken by Le Devoir on the naval question. ${ }^{64}$ On 19 March the House voted on the second reading of the bill. Monk's sub-amendment was soundly defeated, attracting the support of only eighteen MPs. Significantly, Borden was not one of them. The latter's amendment, which had called for the possibility of making an emergency financial contribution to England to help pay for its increasing naval expenditures, also went down to defeat. In this vote, Monk had cast his ballot against his leader. Both of them voted for the final amendment which had called for a six month delay before starting the third reading. The bill then passed its second reading despite Monk's continued opposition. ${ }^{65}$ Unfortunately, due to his continuing illness Monk did not participate in the third reading of the bill. It passed this stage on 20 April 1910 and received the approval of the Senate and finally Royal Assent on 4 May. ${ }^{66}$ However, this did not mean that Monk and Bourassa were ready to end their struggle against the naval act. Throughout 1910, they held a number of anti-navy rallies. Bourassa, with his inimitable sense of timing, made sure to hold one on 20 October 1910 - the day before the scheduled arrival of the one of Canada's new two training cruisers, HMCS Niobe, in Halifax. ${ }^{67} \mathrm{He}$ also noted her arrival in Le Devoir, reminding his readers that she was "Canadian in peacetime, imperial in wartime." 68

\footnotetext{
${ }^{61}$ Robert Rumilly, Histoire de La Province de Québec, Vol. XIV, (Montreal, n. d.), 138.

${ }^{62}$ Debates 1909-1910, Vol. II, col. 3615. Apparently, this petition was ignored.

${ }^{63}$ Ibid., col. 3601.

${ }^{64}$ Ibid., Vol. III, col. 4054

65 Monk's sub-amendment in ibid., cols. 5095-6; Borden's amendment ibid., cols. 5101-2; six months amendment ibid., cols 5191-2. Passed second reading, ibid., cols. 5193-4.

${ }^{66}$ Third Reading, ibid., Vol. V, cols. 7590-92, Monk's absence Béland, 93.

${ }^{67}$ Milner, 19.

68 Johnston, 167.
} 
Highpoint: The Drummond-Arthabasca by-election and the Election of 1911

Monk and Bourassa remained undaunted by the passage of the Naval Service Act, and actually intensified their anti-naval bill agitation, to the degree that even the German consulate in Montreal reported on it regularly. ${ }^{69}$ The chief consequence of this new campaign was the widening of the fissure which separated Monk and Borden on the naval question. This was exposed by Monk's continued public endorsement and open participation in Bourassa's attempt to influence public opinion. The focal points of this renewed effort were an extensive newspaper campaign and an ambitious series of speeches. As a sign of their continued collaboration, Le Devoir published a series of ten articles by Monk on the naval question. Each of them focussed on an aspect or perceived consequence of the naval law and hammered home the nationaliste reasons for opposing it. ${ }^{70}$ During the year the anti-naval law protestors undertook a province-wide tour speaking out against the naval bill. However, this series of speeches soon revealed a significant trend in their relationship. For example, in an anti-navy rally on 17 July 1910 at St. Eustache, Monk had clearly let Bourassa play the starring role. ${ }^{71}$ At least one historian has maintained that by then, Monk had undoubtedly fallen victim to Bourassa's dominant personality. ${ }^{72}$ Most likely, this trend was influenced by Monk's continuing preference to avoid a definitive break with his leader and his lingering illness.

Monk and Bourassa were given a golden opportunity to step up their campaign when a by-election was called for the riding of Drummond-Arthabasca on the 3 November 1910. It pitted the Liberal candidate, Joseph-Edouard Perreault against Arthur Gilbert, a politically unknown nationaliste representing the Conservatives. Gilbert benefited greatly from the support of the best nationaliste speakers throughout his campaign. ${ }^{73}$ From the moment it was called, this riding became the focal point of the nationaliste's anti-naval agitation. While their stand roused the anger of many Conservatives, the latter also realized that they were in a rather embarrassing position. First, Monk was responsible for determining their strategy in this by-election. Second, they earnestly wanted to see Laurier's candidate go down to defeat. Nonetheless, they definitely felt the need to distance themselves from Monk's nationaliste allies. Borden's solution to this vexatious problem was his meek suggestion that "each elector should vote according to the dictates of his conscience." ${ }^{74}$ In the end, Monk and his allies emerged victorious as Gilbert

\footnotetext{
${ }^{69}$ Michael L Hadley \& Roger Sarty, Tin-Pots and Pirate Ships: Canadian Naval Forces and German Sea Raiders 1880-1918. (Montreal: McGill-Queen's University Press, 1991), 56. The German government followed the whole course of the Canadian naval debate with great interest, see 30-52

70 These articles appeared on page 1 of Le Devoir on 4, 10, 17, and 27 June, 2 and 30 July, 16, 20, 25 , and 29 August 1910.

71 Béland, 98.

72 Rumilly, Vol. XIV, 135.

${ }^{73}$ Belanger, 78.

${ }^{74}$ Borden, 1: 289.
} 
defeated Perreault by 207 votes. Together, the alliance of federal Conservatives with the nationalistes had inflicted a telling blow against Laurier's political base in Quebec. ${ }^{75}$

For Borden, the most troubling aspect of the by-election was that it had revealed just how close the Conservative Party was to splitting into two factions over the naval question. As he noted in his memoirs, "the attitude announced by Mr. Monk indicated a serious difference of opinion between the conservatives of Quebec and those of the English speaking provinces. The situation was full of embarrassment. On the one hand, Quebec conservatives affirmed with vehemence that I had gone altogether too far; on the other hand, many conservative leaders in the Englishspeaking provinces were firmly of the opinion that I had not gone far enough."76

Despite this tension between them, Monk informed the editor of Le Devoir in early 1910 that: "Vous pouvez donner un démenti à toutes les rumeurs qui me posent en adversaire de M. R. L. Borden. Mes relations avec lui ont toujours été excellentes."77 Privately, however, Monk was far more pessimistic: "Un raccordement est-il possible? J'en doute beaucoup, car les différences sont trop nombreuses. Je croirais plutôt 1'organisation d'un nouveau parti qui serait un parti essentiellement canadien." 78 Monk never followed through on this idea of founding a new, presumably, nationaliste political party. In the end, Monk and Borden simply decided to continue to agree to disagree, as indicated in Monk's later statement that: "The convictions we [French-Canadian Conservatives] hold upon the naval question differ so greatly from those of our fellow members on our side of the House... I think it is perhaps better for each to follow our course." 79

Nonetheless, on 16 November 1910 Monk indicated that this uneasy truce was still very precarious, After Monk moved, "The House regrets that the Speech from the Throne gives no indication whatever of the intention of the government to consult the people on its naval policy and the general question of the contribution of Canada to Imperial armaments," 80 Borden immediately offered a sub-amendment. The Conservative Party was still far from being united. In fact, as late as $28 \mathrm{March}$ 1911 Borden believed that Monk would not sign the ongoing petition urging him to remain as the leader of the Conservative Party. ${ }^{81}$

The tactics of Monk and Bourassa during this period could not change the fact that the Naval Service Act was now law. Only one avenue of hope was left to the anti-navy group: Laurier had to be defeated in a general election in the hope that the resulting government would repeal the hated naval bill. They were also

\footnotetext{
75 Douglas J. Wurtele, “The Drummond - Arthabaska By-Election of 1910” Dalhousie Review 40:1, (1960), 29.

76 Borden, 1:289.

77 Beland, 95.

78 Ibid., 96.

79 Borden, 1: 289.

80 Ibid., 295.

81 Ibid., 297 and 310.
} 
painfully aware that a nation-wide election could not be fought on the naval issue exclusively. The only exception to this situation was Quebec itself, because it was the only province in which public opinion was sufficiently united and negative on this issue to help them achieve their goal. Laurier's decision to enter negotiations for a more widespread "free trade deal" with the United States, or "reciprocity," would prove to be the requisite nation-wide issue that they were hoping for. As these talks were going on, Bourassa had also reached the same conclusion. His letter of 20 February 1911 to Monk indicated that reciprocity was not as important to him as the naval question: "Plus je réfléchis à la situation, plus il me parait sage que votre groupe Laurier et des Torys se débattre sur le principe de la mesure - et que vous en fassiez rien qui jette la question de la marine à l'arrière plan." ${ }^{22}$ In another letter of 24 February, Bourassa requested further information and documentation from Monk regarding the proposed trade deal. Monk's reply patently indicated that he was moving towards an even closer ideological affinity with Bourassa. ${ }^{83}$ On 7 March Monk informed Bourassa that he was opposed to the reciprocity proposal. However, this letter showed that his opposition was at best lukewarm and that he feared that his motives might be misinterpreted: "Tout de même, je suis contre le traité, mais d'une manière raisonnable et modérée. Je crois qu'il a été conclu à un moment très inopportun et qu'il est tendancieux au point de vue national: je ne veux pas être confondu avec ceux qui croient qu'il faut le rejeter parce qu'il est anti-impérialiste." ${ }^{84}$ On 29 July1911 Laurier called an election for 21 September.

Monk and Bourassa had already decided to collaborate more fully in order to ensure Laurier's defeat even before the prime minister had decided to face the Canadian electorate. On 27 July 1911 Monk wrote Bourassa a few notes which were intended to be a guideline for their political collaboration. Its first article flatly denied the allegations that the nationalistes intended to establish an anti-imperial, anti-English, and nationaliste French-Catholic party. The second reiterated their position on the naval issue and called for a plebiscite. According to them, the repeal of the Naval Service Act was their main goal. The third explained the nature of the commitment which Monk and Bourassa had made to each other. It stressed that there was no formal understanding of any kind between them. They had come together because of their mutual agreement on this and some other matters of deep national interests. The existence of any firm alliance was categorically denied because "each remains free to urge his own views." ${ }^{85}$ Another small section simply stated that in Monk's riding, like others, reciprocity was not widely supported.

On 17 July 1911 Monk wrote Bourassa again, and this letter again showed that he was obviously under the influence of pre-election fever which had hit

\footnotetext{
82 Bourassa to Monk, Montreal, February 20, 1911, Monk Papers, 1:117-8

${ }^{83}$ Ibid., Monk to Bourassa, Montreal, n.d., 121-123; Bourassa to Monk, February 24, 1911, [Quebec City?], 119-121.

${ }^{84}$ Monk to Bourassa, Montreal, 14 June 1911, with an un-numbered sheet entitled Notes. The quote comes from the latter. Bourassa Papers, 385/Monk 23

85 Ibid., Notes.
} 
Parliament Hill. He asked his ally to continue to join him focussing on the issues that were so important to both of them. He remarked that he hoped they would not be found lacking in the noble task that they had undertaken, and which the electors of Drummond-Arthabasca had so wholeheartedly approved. He also wrote, "Nous comptons surtout sur vous et sur votre coopération si efficace dans nos grandes assemblées. Nos efforts depuis le commencement de cette lutte ont été marqués par une harmonie que je n'oublierai jamais et j'ai confiance que cette entente, qui est le meilleur gage de succès, maintiendra parmi tous nos amis jusqu'à la fin." ${ }^{\text {"86 }}$ On 27 July Bourassa reported his observations on two rallies which had been held recently in Quebec: "Nous avons eu, au Fraserville = au St. Blaise [?], deux assemblées splendides - et partout, c'est la même chose: pas de marine - réciprocité indifférente." 87

From this they concluded that they were correct in thinking that in so far as Quebec was concerned the election campaign should be focussed on the naval question. For this reason, he asked Monk to provide him with a copy of a position paper on imperial defence that Laurier had planned to submit to the House prior to the election. On 31 July Monk reported that he had been able to peruse it at the government's print shop and he provided a quick synopsis of it. ${ }^{88}$ On 2 August the Conservative MP provided Bourassa with some notes on Canada's military position. He stressed that: "Je ne voudrais pas que ce qui est écrit paraisse sous mon nom, car je n'ai pas eu et je n'aurai pas le temps de finir le travail. Cela pourrait cependant servir à un de vos rédacteurs." 89

Bourassa later reminded Monk of his conditions for his electoral collaboration in a letter dated 27 January 1912 which indicated that he was still equally opposed to the naval policies of both Laurier and Borden.

Cédant à vos instances, j'ai consenti à vous accompagner, à condition que nous fissions une lutte d'idées, de principes et non un travail de parti. Je vous ai présenté que je ne pouvais pas plus approuver l'attitude de M. Borden que la politique de M. Laurier. Vous étés tombé d'accord avec moi, librement et sans arrière-pensée; et dans toutes nos assemblées nous avons fait adopter une déclaration de principes qui contenait le paragraphe que voici: "Nous censurons également l'attitude de M. Borden et des députés de l'opposition qui, à sa suite, ont réclamé l'adoption d'une politique non moins néfaste." 90

The election campaign in Quebec followed Bourassa's prescription and concentrated on the naval issue, while in the rest of Canada reciprocity dominated.

\footnotetext{
86 Ibid., Monk to Bourassa, Montreal, 17 July 1911, ibid., 410A/Monk 28A.

87 Bourassa to Monk, Outremont, 27 July 1911, Monk Papers 1: 124.

${ }^{88}$ Monk to Bourassa, [Ottawa?], 31 July 1911, Bourassa Papers, 434/Monk 33.

89 Monk to Bourassa, Montreal, 2 August 1911, ibid., 444/Monk 34.

90 Bourassa to Monk, Montreal, 27 January 1912, ibid., 599F/Monk 56F.
} 
In the end, only sixteen of the elected Conservatives from Quebec were aligned with the Monk-Bourassa camp, but they certainly had weakened Laurier's grip on his native province..$^{91}$ Borden was still assured of a working majority, regardless of how this block voted. The first major problem to be addressed by Borden was the composition of his cabinet. The newly elected prime minister wanted Monk to enter the government. Interestingly, both Monk and Borden also wanted Bourassa to join the cabinet, but the latter was clearly not interested, and the idea was not pursued. As Bourassa would later remind Monk: "Avec cette délicatesse et cette bonté de cœur qui vous caractérisent et que je n'oublierai jamais, soyez-en certain, vous m'avez déclaré qu'au cas où $\mathrm{M}$. Borden, qui ne vous avait pas encore donné signe de vie, vous appellerait à faire partie de son ministère, vous ne voulez pas entrer sans moi. Je vous ai répondu, vous ne l'avez pas oublié, que de cela il ne saurait être question." 92 There can be no doubt that Bourassa still distrusted Borden. Additionally, he feared that joining the cabinet would undermine his credibility. Finally, he maintained that he had to concentrate his efforts on the administration of Le Devoir, which he had neglected during the past fifteen months of campaigning against Laurier's naval bill. ${ }^{93}$ Other nationalistes, like Armand Lavergne, felt the same way. He wrote to Borden recommending that Monk should be given the post of minister of Public Works and stated that, "I reserve my decision to abide by Mr. Monk's instructions, if possible." ${ }^{94}$ Therefore, it was all the more imperative that Monk would enter the cabinet along with other nationalistes including GuillaumeAlphonse Nantel.

Consequently, Monk was in a position to choose his post, and he did not lack advice. In a letter written after the fact, Bourassa reminded the Conservative MP that:

Je ne peux pas prendre la responsabilité, de vous dire: 'acceptez' ou 'refusez.' Tout ce que je peux dire, c'est que par votre attitude sur le bill [sic] de la marine, vous avez assumé auprès de vos compatriotes et de tous ceux qui ont eu foi en vous une responsabilité, un mandat moral, que vous ne pouvez écarter. Si M. Borden vous appelle, ce sera à vous de juger de quelle manière vous pouvez exécuter votre mandat le plus fidèlement: en acceptant ou en refusant. Posez vos conditions nettement. Si elles sont acceptées, entrez. Et si plus tard on cherche à les éluder, sortez. ${ }^{95}$

In the end, Monk decided to enter the cabinet as minister for Public Works. This decision was based on Borden's election promise to repeal the naval bill, as well as

\footnotetext{
91 J. L. Finlay and D. N. Sprague, The Structure of Canadian History, (Scarborough, Ontario, 2nd Edition, paperback), 514 and 288.

92 Bourassa Papers, "599H/Monk 56H".

93 Ibid., 599H-I/Monk 56H-I.

94 Armand Lavergne to R. L. Borden, Quebec City, 8 October 1911, Monk Papers 1: 130.

95 Bourassa Papers, 599I/Monk 56I.
} 
a few other important concessions. ${ }^{96}$

With his entry into the cabinet, the nationalistes were ready to press on with their campaign for a repeal of the naval bill, or at least a plebiscite on the naval question. When his advocacy prompted criticism within the Conservative Party, Monk replied with this outburst on 23 November 1911: “...we are loyal subjects of the Crown, we do not approve of this plan and of the navy, we use our rights to criticize it, it was adopted without any mandate from or consultation with the people; we pledge ourselves to accept unreservedly the verdict of the people consulted on this subject." ${ }^{\text {97 }}$ However, Borden had no immediate intention of reviving the political vortex of the naval issue. He was quite content to let the Naval Service Act remain in limbo by refusing to implement it fully without repealing it. Fate was to deny him the opportunity to avoid the naval issue for long, and in the very near future he would be forced to revisit it.

\section{Epilogue: The Crusade fades out}

The naval issue continued to cast its shadow over Parliament Hill during the autumn and winter of 1911. However, the nature of the debate was more subdued as the great pre-election rallies gradually disappeared. After the election, Monk's health rapidly deteriorated; this did not bode well for the nationaliste cause. Simultaneously, his relationship with Bourassa had begun to erode noticeably, in part because of Borden's delay in honouring his election promise to repeal the Naval Service Act. This trend is obvious in three letters that Monk wrote to his election ally in this period. In the first, dated 29 October 1911, Monk lamented that he had been unable to meet with Bourassa during a recent stay in Montreal. He noted that he was still the continuing object of disrespect in Ottawa and that he disliked the gulf which continued to separate him from his friends. He then closed with this very poignant plea: "Donnez-moi donc un signe de vie pour que nous puissions nous rencontrer et causer comme autrefois." ${ }^{98}$ On 10 November he wrote that he had hoped to meet with Le Devoir's editor in Montreal on a scheduled trip, but he had forced to cancel it at the last moment. He mentioned his concern about the heavy workload of his department, and singled out the problem of patronage. He also stated that, "J'attends avec inquiétude le discours du trône, il me semble que mes collègues n'en réalisent pas pleinement l'immense portée." 99 The last of these letters was dated 17 December. He also discussed a recent visit of some of his relatives. This led him to ponder about another of his relatives: "Je pense un peu au nationaliste H. B. un cousin lui aussi et je me demande si vous ne pourriez pas venir passer une soirée chez moi et avoir une bonne causerie comme autrefois pendant la

\footnotetext{
96 Mason Wade, The French Canadians 1766-1967 (Toronto Macmillan Canada, revised edition, 1968), 1: 614 .

97 Borden, 341

98 Monk to Bourassa, Montreal, 29 October 1911, Bourassa Papers, 556B/Monk 42B.

99 Monk to Bourassa, Montreal, 10 November 1910, Bourassa Papers, 565B/Monk 44B.
} 
guerre navale ou maritime. J'ai tant de choses qui vous intéresseraient!"100

On 27 January 1912 Bourassa dropped a literal bombshell on Monk. It took the form of a fourteen page, typewritten letter. In it, the editor of Le Devoir chastised Monk for his failure to resolve the patronage problem in his ministry, as well as the lack of progress on the naval issue. He reminded the Tory MP that he had been among the first to publicly support Monk's position at Lachine in November 1909. Bourassa also emphasized the support that his paper had given him throughout the session of 1910. He then added: "En faisant la part des exigences particulières de votre comté, vous avez reconnu avec moi que la Réciprocité écartée, la politique navale ou plutôt le problème impérialiste demeurerait la question sur laquelle groupes et partis seraient appelés avant longtemps à s'orienter, peut-être à se disloquer, puis à se reconstituer sur de nouvelle bases." 101

Bourassa maintained however that it was not too late for Monk to redeem himself. "Je vous répète du fond du cœur: faites votre devoir public, luttez dans le ministère pour les causes que nous avons défendues ensemble, fortifiez-vous en réveillant, si c'est possible, la fierté et l'énergie des députés qui se sont fait élire grâce à nos luttes, à nos idées, à nos principes - et même, pour plusieurs, je pourrais dire grâce à cela seulement, - et je serai amplement récompensé." 102 Monk's lengthy reply was dated 11 February and in it he noted that "Vous ne savez pas combien j'ai été blâmé, censuré même, à cet endroit." ${ }^{103}$ He apologized for the delay in his response, but claimed to have had great difficulty in finding time to draft a cogent reply to Bourassa's call to end his apparent lethargy. He defended his progress on the issue of patronage, arguing that much had been accomplished. He also reiterated his continued loyalty to the nationaliste cause: "Je me suis contenté, la plupart du temps, de reconnaitre que si on le prenait ainsi, j'admettrais l'accusation et j'étais prêt à en assumer toutes les conséquences, définissant la position prise par les soi-disant nationalistes groupés ensemble sur la question de la marine et autres questions connexes, pendant toute la durée de la lutte, et justifiant notre résolution dirigée contre les deux chefs des deux partis en présence. Il me semblait que c'était assez." 104

Although Borden had been able to avoid the quagmire of the naval issue through most of the early part of his mandate, his luck finally ran out in March 1912. ${ }^{105} \mathrm{He}$ accepted an invitation for a Canadian delegation to visit England to discuss the naval situation directly with the Admiralty and the Imperial political leadership. This trip was scheduled for July 1912, and Borden's most pressing problem was deciding upon the composition of this delegation. One of his preferred

\footnotetext{
100 Monk to Bourassa, Ottawa, 17 December 1912, Ibid., 582A-B/Monk 51A-B .

101 Bourassa to Monk, Montreal, January 27, 1912, Ibid., 599G/Monk 56G.

102 Ibid., 599L-M/Monk 56L-M.

103 Monk to Bourassa, Ottawa, 11 February 1912, Ibid., 610F/Monk 58F. The tone of this complaint is eerily similar to his complaints of 1904 .

104 Bourassa to Monk, [Montrea1?], 12 February 1912, Ibid., 611/Monk 59.

105 Ibid., 235.
} 
candidates was Monk: "I was most anxious that Mr. Monk should accompany me but he showed [a] marked disinclination which arose, probably from his wellknown reluctance to be concerned in any measure of this character." ${ }^{106}$ In the end, Monk pleaded that he was too ill to make the trip.

In England, officials of the British government and the Admiralty had no difficulty in persuading Borden of the gravity of the situation. Consequently, the newly elected prime minister decided that Canada should make an emergency contribution to the Royal Navy. However, he still had to find some way of resolving the dilemma posed by Monk and the nationalistes. To this end, he managed to obtain Canadian representation on the Committee for Imperial Defence, even though it was in reality nothing more than an impotent consultation body. Borden also asked Churchill for two documents detailing the dire predicament of naval strength. One of these was meant for publication in Canada, while the other was to remain confidential, with distribution to members of the Canadian government. At first, the former failed to meet with his approval. "In returning it, I wrote to him [Churchill] that if this contribution was the best we could expect it would be idle for him to anticipate any results whatever from the Government or the people of Canada." 107 The secret memorandum, however, was well suited for his purposes as was the revised public statement.

In September he returned to Ottawa and began to lay the groundwork for his Naval Aid Bill. This meant convincing not only the public but also the dissidents within his party of the necessity of providing direct naval aid to England. Predictably, the latter goal was much more difficult. Borden admitted as much in his memoirs: "but of far more serious concern was the persistent rumour that my friend and colleague, F. D. Monk was hostile to us on naval aid." 108 Later that month, he presented the secret Admiralty document to his cabinet. In his memoirs ne noted, "Following perusal of the documents, discussion arose as to the advisability of consulting the people by plebiscite. Monk admitted that the situation was grave and emergent but was very strong in his opinion that this course should be followed and Nantel was his echo."109

On 11 October 1912 Monk informed Borden that: "he would retire unless we consult the people." ${ }^{110}$ On 14 October Borden submitted a draft of the Naval Aid Bill to the cabinet, and later noted that Monk "did not say a word." 111 . He also stated that Monk had promised "not to oppose us except in the naval issue." 112 Monk resigned his cabinet post on 18 October but it appears that he had most likely

\footnotetext{
106 Borden, 355.

107 Ibid., 365.

108 Ibid., 399.

109 Ibid.

110 Cited in Brown, 238.

111 Borden, 400.

112 Ibid., 403.
} 
decided to resign long before that date. ${ }^{113}$

The next day, Bourassa was at a meeting when the news broke of Monk's resignation. Bourassa had already publicly urged Monk to resign as early as 4 September 1912 in protest against Borden's naval policy. ${ }^{114}$ Consequently, the decision itself, but perhaps not its timing, should not have been a surprise to Bourassa. In any case, a delegation of five nationalistes was formed and instructed to meet with Monk as soon as possible. When they met, Monk informed them that Borden had decided to repeal the Naval Service Act once his new naval bill was enacted. This measure would give England an immediate naval contribution without seeking the prior approval of the electorate. The outgoing cabinet minister also commented that Borden had promised to consult the people on a more permanent naval policy as soon as possible. Bourassa's hastily written notes also state that: "Monk admet que par les derniers documents reçus, [1']Angleterre a besoin et que si [un] plébiscite [est] accordé, [il] viendrait demander à Québec de voter oui." 115

Monk explained that for him it was now a question of honour, given his public stand on this issue. One of these delegates agreed with Monk's decision but suggested that he demand this plebiscite in the House of Commons. If Borden refused, then Monk should resign his seat to fight the resulting by-election on this issue. Monk's subsequent letter of resignation was cited during the debate on this bill. In it, Monk had written

I regret to find that I cannot concur in the decision, arrived at by the Cabinet yesterday, to place on behalf of Canada an emergency contribution of $\$ 35,000,000$ at the disposal of the British government for naval purposes with the sanction of parliament but without giving the Canadian people an opportunity of expressing their approval of this important step before it is taken. Such a concurrence would be at variance with my pledges, and the act proposed is of sufficient gravity to justify my insistence. ${ }^{116}$

The naval question had gone almost full circle, and Monk was once again an ordinary MP.

Monk's resignation did not deter Borden from pursuing his course. On 27 November he held a meeting with his Quebec delegation and outlined his policy and intentions. During this meeting, to the ire of Bourassa, several nationalistes decided to support the government. ${ }^{117}$ Bolstered by this partial success, the prime minister presented the bill which he ultimately forced through the House by

\footnotetext{
113 Bélanger, Albert Sevigny, says Monk had made his decision on 26 September 1912, 147.

114 English, 191. See his footnote on 199 for the date of Bourassa's editorial.

115 Bourassa Papers, handwritten notes by Bourassa titled Demission Monk, Monk \# 62. This document does not have a specific Bourassa number. As well, it is impossible to determine the chronological order of Monk 62A and B. The quote comes from one of these two pages.

116 Debates 1912-1913, Vol. III, col. 4510.

117 Borden, 403; see also Brown, 238-40.
} 
enforcing closure for the first time in Canadian parliamentary history. In the Senate, Laurier's majority ensured that the bill was returned to the House of Commons with the recommendation that it be "submitted to the judgement of the people" 118 either through a general election or perhaps a plebiscite. Borden had earlier refused Laurier's offer of Senate approval for his bill if he agreed to fully implement the Naval Service Act. Although Borden promised to introduce a new naval measure at a later date, he never did.

Monk's illness limited his role in the debate on the Naval Aid Bill. ${ }^{119}$ Lavergne appealed to Monk to take his seat and lead the fight against it but he refused. Lavergne described Monk as being "désabusé, malade, moralement ébranlé par des duels répétés" and further "[il] se détachait de son parti sans pouvoir adhérer au parti adverse." ${ }^{20}$ Monk received many letters of support for his unwavering stand on the issue. One of these downplayed the idea of a "naval emergency" of 1912. ${ }^{121}$ Another letter, dated 17 February 1913 was to have a profound influence on his future actions. Its author recommended that: "If you still feel the fire you felt at the time of the Lachine speech, you should come forward." 122 Monk later sent a copy of this letter to Bourassa. ${ }^{123}$ Monk's final contribution to the naval issue took place on 3 March 1913 when he was interviewed by the Montreal Gazette. Somehow, Bourassa obtained a copy of Monk's notes for this interview. In them, we see that Monk debunked Borden's argument regarding the significance of Canadian representation on the Committee of Imperial Defence. He also stressed that the British North America Act had restricted the Canadian Parliament to measures regarding the defence of Canadian territory. He then reiterated the need for a referendum on the naval issue. ${ }^{124}$

Reactions to this interview came in quickly, and included an invitation to address the Canadian Institute of Journalism on the naval issue. ${ }^{125}$ On 14 March he wrote P. E. Blondin, a Quebec Conservative MP who had decided to support Borden's policy. In this letter, Monk explained his reasons for giving this interview.

Mon entrevue avec un journal a été rendue nécessaire parce que mes

\footnotetext{
118 Johnson, 201.

119 Béland, 93. See also p. 1 of Monk's Interview Notes for the Montreal Gazette,13 March 1913, a copy of which is in the Bourassa Papers. The latter does not have either a Bourassa number or a Monk number.

${ }^{120}$ Cited in Rumilly, Vol. XVIII, 19-21.

${ }^{121}$ C. S. Campbell to Monk, [Bermuda?], 30 December 1912, Monk Papers, 1: 192-3

122 C. S. Campbell to Monk, [Florida ?], 17 February 1913, ibid., 2: 9-10.

${ }^{123}$ Monk to Bourassa, Montreal, 16 March 1913, Bourassa Papers, 917/Monk 65.

124 Monk Interview Notes, 2-3, ibid. Unless stated otherwise, all information presented on this document comes from this source. The published interview is at "Hon. F. D. Monk on Some Issues" The Montreal Gazette 138: 53 (3 March 1913), 11.

125 Monk Papers, Vol. II, n.p. They include G. N. Ducharme to Monk, Montreal, 4 March 1913 and Mille. A. Quintal to Monk, Montreal, 5 March 1913. For the invitation to address the Canadian Institute of Journalism see: W. H. Stewart to Monk, Montreal, 7 March 1913, ibid.
} 
amis m'ont reproché mon silence, et j'ai trouvé que ce silence pouvait être interprété d'une façon très défavorable pour moi. Les lettres sans nombre que j'ai reçues m'ont convaincu que mon absence d'Ottawa était attribuée à la crainte de déplaire au Gouvernement ou à mes amis. J'ai même appris, et cela m'a fait grand peine, que mes anciens alliés disaient pis que pendre de moi, et comme ce procédé m'a paru bas et injuste, j'ai cru devoir rectifier et faire connaitre ma position sans aucune évoque afin de me protéger. ${ }^{126}$

On 17 April Monk wrote Bourassa about two recent articles in Le Devoir which had dealt with the naval issue. ${ }^{127}$ In a letter dated 17 December, Bourassa queried Monk as to his plans for the next session of Parliament. ${ }^{128}$ It was a hopeful sign that their friendship would survive the setback of the latest naval crisis. On 3 March 1914 Monk announced his resignation from the House due to his continued ill health, and he died later that year. ${ }^{129}$

The outbreak of the First World War in August 1914, found the Royal Navy with a more than comfortable lead in dreadnought battleships and battlecruisers over its imperial German rival. ${ }^{130}$ Once war was declared, the Royal Navy quickly added three more battleships to its insurmountable lead by confiscating ships that were being built for other nations in British yards. ${ }^{131}$

\section{Conclusion}

There can be no doubt as to the sincerity of Monk's convictions on the naval issue. The same also applies to his willingness to accept the verdict of the Canadian people on a Canada-wide plebiscite on this issue. His early and steadfast stance won him the support of many nationalistes, including Henri Bourassa. Politically, Monk and Bourassa's coalition effectively eroded Laurier's strength in Quebec and helped to cause his defeat in the election of 1911. However, they had failed to win the balance of power position that they desired and Borden could afford to ignore the small nationaliste group within his caucus. The big loser in the naval issue was their vision of Canada as a union of two equal national groups loosely tied to England. Together with the litany of other crises which helped to keep French and English-Canadians apart, these crises helped to stimulate the rise of a more Quebec-centric variant of French-Canadian nationalism. Unfortunately,

\footnotetext{
126 Ibid., Monk to P. E. Blondin, Montreal, 14 March 1913, 2.

127 Monk to Bourassa, Atlantic City, N. J., 13 April 1913, Bourassa Papers, 935/Monk 66.

128 Bourassa to Monk, Montreal, 17 December 1913, Monk Papers 1: 236-7.

129 A copy of this announcement is in the Bourassa Papers and it bears the number Monk 76.

130 Matthew Seligmann, Frank Nägler and Michael Epkenhans, eds., The Naval Route to the Abyss: The Anglo-German Naval Race 1895-1914. (Farnham, Surrey: Routledge for the Navy Records Society, 2015), 423

131 Siegfried Breyer, Battleships and Battlecruisers, 1905-1970. Trans. by Alfred Kurti, (New York: Dobleday,), 1973, 445. One of these ships was renamed HMS Canada.
} 
Monk never managed to come to grips with his personal dilemma of how to stay true to his nationaliste vision of Canada and still remain in the Conservative Party. His unwillingness to make a clean break with his party and its leader until 1913 was arguably his biggest failing and definitely differentiates him from Bourassa.

Today, Monk has been relegated to a relatively minor position in the Canadian pantheon of political figures. His role in the nationaliste opposition to the naval bills of 1910 and 1912 is often either mentioned only in passing or simply glossed over completely. ${ }^{132}$ There is no doubt that Monk's legacy and memory has been fully eclipsed by that of the more colourful and evocative Bourassa. At the very least, Monk's career should remind us that Bourassa was not the only standard bearer of French Canadian nationalism in this period.

${ }^{132}$ For example see the treatment of Monk in Commander Tony German, The Sea is at our Gates: A History of the Canadian Navy. (Toronto:McClelland and Stewart, 1990), 26. Trofimenkoff, 179, mentioned Monk once. He is not listed in Milner's index. 